\title{
Investigation of the Effect of "China Dream" in the Ideal and Belief Education for College Students
}

\author{
Ning Yang ${ }^{1}$ \\ ${ }^{1}$ Party Committee Office \\ Guangxi Open University \\ Guangxi Open University, gxou \\ Nanning, China \\ e-mail: yangning9521070@163.com
}

\author{
Feng Qin ${ }^{2}$ \\ ${ }^{2}$ Department of Facility and Laboratory Management \\ Guangxi University for Nationalities \\ Guangxi University for Nationalities, gxun \\ Nanning, China \\ e-mail: qinfengxiren@126.com
}

\begin{abstract}
China dream" brings new opportunities to the education of college students, it is significant to lead college students to establish scientific ideal and belief, state that "China dream" play an important part in making effectiveness in the ideal and belief education of college students, in bringing forth new ideas, in enhancing their ideals and beliefs of the country, in helping them to identify scientific theory, in strengthening their subject position in the process of dreams.
\end{abstract}

Keywords-"China dream"; the ideal and belief education for college students; effect

\section{INTRODUCTION}

Universities are the important position of the education of Marx theory. It is a currently main task for the colleges and universities to guide the ideological and political education work with "China dream", universities should guide the contemporary college students in fostering ideals and beliefs for socialism with chinese characteristics in virtue of the rich connotation of "China dream", and help them to internalized in the mind, to externalized in the action, consciously unremittingly struggle for achieving the common ideal "China dream ".

\section{Problems IN THE IDEAL AND BELIEF EDUCATION FOR COLLEGE STUDENTS}

With the development of globalization, various kinds of values and cultural trend pour into China, the spirit of college students are being impacted and rusted by negative and rotten ideas, these ideas obscured the smooth implementation of the ideal and belief education for college students.

\section{A. The content of education were ossified and lagging, lack of pertinence}

The content of the ideal and belief education for the contemporary college students were word-mongering divorced from actual life over a long period of time, lagged behind social development. Currently, The content of the ideal and belief education for the contemporary college students were limited to the abstract conception in the teaching material yet, it didn't contact to actual life closely enough, it was far from

This research was supported by the Ideological and Political Education Theory and Practice Project of Guangxi Universities No.2012LSZ043. ideological reality. The content of the college students were inconformable to social reality which they contacted, the abstract conception in the teaching material could't explain the practical problems, they easily emerge ambivalence, their enthusiasm for learning and initiative greatly reduced as well. Therefore, only the content of the ideal and belief education for the college students keep up with the times and constantly updated can raise the its pertinence.

\section{B. The methods of education were single and backward,lack of pragmaticality}

"Instill" methods overemphasize the dominant of educators, ignore the initiative of educatees, it means overlooking the subject status of college students. The ideal and belief education attribute to values education, educators are asked to lead educatees to judge and choose from value management on the basic of cognition. The process of education should even more be learning process, be unconsciously process which go through active perceptiveness and judgment. "talk volubly of principle" methods make college students hard to break through theory concept, and hard to experience and understand cultural knowledge clearly. Therefore, we must constantly improve the methods of education to raise the its pragmaticality.

\section{The surroundings of education were isolated and separated,lack of concordance}

The surroundings of school, family and society both have important influence to how the ideal and belief of college students come into being."The only way in which adults consciously control the kind of education which the immature get is by controlling the environment in which they act, and hence think an feel. $\cdots .$. An intelligent home differs from an unintelligent one chiefly in that the habits of life and intercourse which prevail are chosen, or at least colored, bye the thought of their bearing upon the development of children."Therefore, only strengthen the coordination of school, family and society, combine into resultant force, can build the surroundings which are favorable to develop personal ideal and belief, can the ideal and belief education for college students achieve the best effect. 


\section{MUCH SIGNIFICANCE THAT "CHINA DREAM"MEANS TO} REINFORCING THE IDEAL AND BELIEF EDUCATION FOR COLLEGE STUDENTS

"China dream" should be took into the ideal and belief education for college students system, and "China dream" should be combined with personal dream, only then might the education be closer to the actual life of college students, and might the pragmaticality of the ideal and belief education for college students been raised.

\section{A. "China dream" can raise the pragmaticality of the ideal and belief education for college students}

\section{1) It conforms to the requirement of times}

"China dream" is a dynamic category, with the connotation of times constantly enriching, it is a new theme and a good story to the ideal and belief education for college students. China is changing constantly as well as the world, the conditions of strategic opportunities are changing constantly accordingly. In currently China, There are lacking of honesty and moral disordering in some areas, socialist core value system still should urgently be used to guide the ethos. There are much new situations and new challenges in keeping our Party advanced quality and pure quality, in enhancing the Party's art of leadership and governance, in raising the Party's capacity to resist corruption, prevent degeneration and withstand risks. The problems of interests still more outstanding which are about education, employment, social security, income distribution, health care, housing, safety in production, public security. ${ }^{[1]}$ They create huge challenges to the construction of the ideal and belief for college students.

2) It conforms to the requirement of growth law of college students

Contemporary college students have lively minds, they have much dreams and vitality, but they are easily influenced by environments. It results in perplexed and bewildered when they are selecting and establishing their dreams, further, it make personal dream and pursuit hard to root, blossom and fruit, especially when they are confronting to the situations that ideology diversification intertwine and increasingly competitive pressure," China dream" comes from reality and higher than reality, with reference to the national dream at all times and in all over the world, we hold on the trend of the developing world and blueprint for the future of China, truly record the hardship about the dreams of national liberation and restoring which the chinese nation have been pursuiting. "China dream" grasp the growth law of college students and features in the ideology, the outlook on life, values and world outlook that "China dream" reflects are inherently integrating to which the chinese college students should have. Therefore," China dream" have profound educative effect, highly infectivity and attraction, it accords with the characteristic of Physical and mental growth which belong to contemporary college students.

3) It conforms to the law of the ideological and political education
"China dream" is aggregation and combination which comes from the great national dream and small personal dream."China dream" closely related with the study and life of college students, there are very good bonding point in talent, employment, development etc of the great national dream and small personal dream. The ideal and belief education ought to adhere to the inherent law of the ideological and political education, it can guide the ideal and belief education for college students with "China dream", uide the college students to remember their historical mission, to overcome the negative impact by money worship, hedonism and egoism when they are establishing personal ideals and life goal. It also ought to develop their sense of highly social responsibility, encourage them consciously to closely connect the destiny of man with the fate of country and nationalities, to obtain power for struggling and advancing from the great "China dream".

\section{B. "China dream" can innovate new methods of the ideal and belief education for college students}

1) It takes the function of inspiration and vectoring seriously

In order to make "China dream" infiltrate through the ideal and belief education for college students, besides the methods as theory explanation in classroom, publicity and education, moralistic inculcation, we can also apply the methods "inspiration and vectoring" such as interactive education, participation-based teaching, edification, self-education etc to help college students to increase self-confidence, to rationally orient personal dream, to promote their positive behaviors, to consciously and initiatively establish the faith which they make arduous efforts for realizing the great rejuvenation of the chinese nation "China dream". With the process of applying the methods "inspiration and vectoring" in the ideal and belief education for college students, the college students, capacities of self-learning are enhanced and the college students' values of life to self sublimation are realized.

\section{2) It can play a role in invisible education}

In order to make "China dream" infiltrate through the ideal and belief education for college students, on the one hand, we should vigorously promote the remarkable development achievements China has made since the initiation of reform and opening-up in the past thirty years by the methods such as campus network, QQ group, wechat, blog, broadcast and poster etc, the ideal and belief education for college students should accord to plan and purpose in order to help college students to prove effective to "China dream". On the other hand, in the light of the ideological reality which reflects openminded and great craving for knowledge of college students, we should make good use of various medium to build ad hoc atmosphere, use invisible education which is unconscious and indirect to make college students subliminally suffered the edification, in this way, we can raise the effect of the ideal and belief education for college students.

3) It demands us to strengthen guidance of practice education

We should vigorously carry out practice activities which are about "China dream" theme, lead college students to visit 
sacred place of revolution, to feel personally the noble qualities of revolutionary martyrs who pledge their lives for national independence and the liberation of the people. We should encourage them to toughen to grass-roots unit, o understand society, o experience and observe situations of the people, to help them understand and courage to assume responsibility historic mission and social responsibility. In order to strengthen educational effect in practice, we should organize them to participate in the volunteer work on important historical events and festival, make them to apperceive and experience "China dream" personally, to do from the little things around, to fell into the habits of service and dedication. We should also organize them visit model worker, make them to hear exemplary deeds with their own ears from model worker which are about selfless dedication, self- discipline and hard struggle, lead them to establish noble ideals and positively, to throw themselves into the great practice to realize "China dream".

\section{THE EFFECT EMBODY OF "CHINA DREAM" IN THE IDEAL AND BELIEF EDUCATION FOR COLLEGE STUDENTS}

"China dream" was officially put forward as the common ideal of the whole nation by General Secretary Jinping Xi when he was visiting the "road of rejuvenation" exhibit."China dream" is a valuable spiritual legacy of all of the chinese nation, is a educative resources full of chinese characteristics, it have rich and profound connotation, it is rich in cohesion and appeal, it can effectively help to build up sense of nationhood and help to promote acceptability to the ideal and belief education for college students.

\section{A. It can enhance sense of nationhood of the ideal and belief of college students}

1) Encourage college students to closely share weal and woe with country

"China dream" show the clear mind which is fused by sinicism and world breast. ${ }^{[2] " C h i n a ~ d r e a m " ~ i s ~ " e t h n o l o g i c ~}$ dream" as well as "people's dream", moreover, is "national dream"."People's dream" is personal ideals," ethnologic dream" and "national dream" are social ideal," China dream" is just about values which reflect complement each other by social ideal and personal ideals, glorious long Chinese civilization-modern vicissitudes humiliation-remarkable construction and reform, China showed sinicism by grandness, vicissitudes and honour, made it China brand.To achieve the Chinese nation' $\mathrm{s}$ bright prospect on the road to revival is a basic clue which through chinese history, unscramble chinese history from the fantacy journey "To achieve the Chinese nation' $\mathrm{s}$ bright prospect on the road to revival", make patriotism of college students conscious value pursuit.

2) Inspire college students to be bold in struggling and undertaking

“ 'China dream' only can be built by China, but it belongs to the whole world". ${ }^{3]}$ "China dream" is an integral component of the world dream, from "China dream" to "africa dream" and "world dream" $[4]$,the pursuit of chinese people is stitched together with the expectation of people all over the world, in order to achieve "China dream" ,it must fundamentally rely on hard struggling by chinese people, at the same time, it also needs the understanding and support by people all over the world, therefore, "China dream" not only brings benefit to chinese people, but also to people all over the world. ${ }^{[5]}$ "China dream" is able to foster college students global consciousness and world vision, help them to consciously contribute knowledge and ability, make them to strive to become a responsible chinese, to improve the national image and to promote international acceptance.

\section{B. It can help college students to rationally identify scientific theory}

\section{1) Strengthen their correct political direction}

In the process of the ideal and belief education for college students, we must help them to set up correct political beliefs, to strengthen correct political direction. March 17, 2013, General Secretary Jinping $\mathrm{Xi}$ further point out, in order to realize "China dream", we must stick to the trend of China, promote the spirit of China, agglomerate China Power. ${ }^{[6] " C h i n a ~ d r e a m " ~ i s ~ i d e a l ~ a n d ~ f a i t h ~ p a r t ~ o f ~ M a r x i s m, ~ i t ~}$ enrich the connotation of socialism with Chinese characteristics, it is a organic unity which shows temporal spirit and scientificalness," China dream" is the common ideal of chinese nation, is also ultimate goal."Both history and reality indicate, nothing but socialism can save china, nothing but socialism with chinese characteristics can make China developmental, it is a verdict of history and choice of people". ${ }^{[7]}$

\section{2) Stimulate their powerful achievement motivation}

The core power of arousing motivation is ideal and belief. ${ }^{[8]}$ The correct ideal and belief are beneficial to shape achievement motivation of college students, achievement motivation can promote them to develop positive values, once they have positive life value and wish to quest for success, motivation will take shape which is able to boost and inspire morale and unremitting efforts for dream achievement."China dream" is the common ideal of chinese nation, it call for jointly completing by the Chinese nation, it is capable of uniting the power from the people of all nationalities in the country, of inspiring morale from the people of all nationalities in the country, of utmostly arousing various positive factors of the entire chinese-speaking world, of encouraging all the chinese people to strive ahead for the ultimate ideal "great renaissance of the Chinese nation".

\section{It can strengthen college students' subject status in fulfilling ideal}

\section{1) Inspire them to pioneering and innovative}

The contemporary college students, subject consciousness is very prominent, they have very strong thirst for knowledge about changing and innovating, they are a group of the most innovative ability, they are never satisfied with previous achievements, they are no lack of consciousness of innovation, ability of innovation and courage of innovation, 
they yearn for respecting and recognition from society. So college students' subject role are able to be used for ideal and belief education, we should lead them to explore how to combine personal hobbies and interests with ideals and beliefs, make them to fully display their spirits of innovation in the relaxed environment which they are familiar with. Furthermore, to explore new methods with spirit of innovation and to initiate new prospects."China dream" means the innovation of the dream, it comes from brand new practice and exploration, as the backbone of realizing "China dream", the contemporary college students need more to constantly practise, keep thinking and keep learning in order to fulfill "China dream" with spirit of the time "pioneering and innovative".

\section{2) Impel them to hone their will}

At socialism initial stage is now the maximum conditions to present China, the process of realizing "China dream" is historic reform and development, China also can' t surpass this maximum conditions, the two "double" is periodic achievement of "China dream", it reflects the organic unity that by quantity change and quality change, with the reform and opening up a longitudinal propulsion, problems and challenges that present China must face are more and more complex. Therefore, we must rationally deepen the understanding to "China dream" of college students, furthermore, we should turn their political beliefs into conscious actions," strengthen the belief in Marxism, strengthen the faith in Socialism, boost confidence in reform and opening up and modernization construction, increase trust in party and state". Meanwhile, we must boost confidence in road of socialism with chinese characteristics, hone their tenacious will in social practice. College students is the main body of realizing personal dream and "China dream", history suggests that there is always a gap between reality and ideal, dream is bright, but the road have twists and turns when chasing dreams, there are heavy difficulties and challenges in the process, only the strongwilled can ultimately become dream finisher.

\section{REFERENCES}

[1] Dongfang Meng, Zibo Wang. the connotation, structure and path optimization of "china dream"[J].Chongqing Social Sciences,2013(5).

[2] Yuting Luo, Shanshan Shi. China dream education: a new topic of the ideological and political education for college students [J]. Studies In Ideological And Political Education,2013 (9)Volume 1.

[3] $\mathrm{Xu} \mathrm{Wu}$. Build "china dream" for the world: how to torsion China soft power deficit [M].Beijing: Xinhua Press,2009:8.

[4] Jinping Xi:Always be a reliable friend and sincere partner -- a speech at Tanzania Nyerere International Conference Center[N].People's Daily,2013-3-26.

[5] Jinping $\mathrm{Xi}$ : The times ahead the trend of promoting world peace and development -- Speech at the University of International Relations in Moscow[N].People's Daily,2013-3-24.

[6] Jinping Xi: Speech at the closing meeting of the first session of the 12th National People's Congress[N].People's Daily,2013-3-18.

[7] Jinping Xi: Unswervingly upholding and developing socialism Chinese characteristics[J].Party Construction,2013(2).

[8] Ronghua Shi.Social psychology [M]. Shanghai: Shanghai Education Press, 1996 : 92. 